\title{
A New Method Based on Thermal Response Tests for Determining Effective Thermal Conductivity and Borehole Resistivity for Borehole Heat Exchangers
}

\author{
Aneta Sapińska-Sliwa ${ }^{1}$, Marc A. Rosen ${ }^{2}{ }^{(1)}$, Andrzej Gonet ${ }^{1}$, Joanna Kowalczyk ${ }^{3}$ and \\ Tomasz Sliwa ${ }^{1, *}$ \\ 1 Faculty of Drilling, Oil and Gas, Department of Drilling and Geoengineering, Laboratory of Geoenergetics, \\ AGH University of Science and Technology (AGH UST), al. Mickiewicza 30, 30-059 Krakow, Poland; \\ ans@agh.edu.pl (A.S.-S.); gonet@agh.edu.pl (A.G.) \\ 2 Faculty of Engineering and Applied Science, University of Ontario Institute of Technology, \\ 2000 Simcoe Street North, Oshawa, ON L1H 7K4, Canada; marc.rosen@uoit.ca \\ 3 Faculty of Mathematics and Natural Sciences, University of Rzeszow, Al. Rejtana 16c, 35-959 Rzeszów, \\ Poland; jkowalcz@univ.rzeszow.pl \\ * Correspondence: sliwa@agh.edu.pl; Tel.: +48-12-617-22-17
}

Received: 10 January 2019; Accepted: 17 March 2019; Published: 20 March 2019

\begin{abstract}
Research on borehole heat exchangers is described on the development of a method for the determination, based on thermal response tests, of the effective thermal conductivity and the thermal resistivity for borehole heat exchangers. This advance is important, because underground thermal energy storage increasingly consists of systems with a large number of borehole heat exchangers, and their effective thermal conductivities and thermal resistivities are significant parameters in the performance of the system (whether it contains a single borehole or a field of boreholes). Borehole thermal energy storages provide a particularly beneficial method for using ground energy as a clean thermal energy supply. This benefit is especially relevant in cities with significant smog in winter. Here, the authors describe, in detail, the development of a formula that is a basis for the thermal response test that is derived from Fourier's Law, utilizing a new way of describing the basic parameters of the thermal response test, i.e., the effective thermal conductivity and the thermal resistivity. The new method is based on the resistivity equation, for which a solution giving a linear regression with zero directional coefficient is found. Experimental tests were performed and analyzed in support of the theory, with an emphasis on the interpretation differences that stem from the scope of the test.
\end{abstract}

Keywords: geoenergetics; ground source heat pumps; borehole heat exchangers; thermal response test; borehole thermal energy storage

\section{Introduction}

A significant increase of new heating and heating/cooling installations that is based on heat pumps and borehole heat exchangers (BHE) has been recently observed in many countries, including Switzerland [1], Germany [2], Sweden [3], Canada [4], and the United States [5]. Borehole thermal energy storage (BTES) permits the extraction of heat from the ground for heating in winter and the extraction of cool (i.e., the input of heat) for air conditioning in summer [6,7]. A BTES is a type of geoenergetic system, which also includes energy systems that are based on geothermal waters. Geothermal energy utilisation is usually more problematic when it is connected with geothermal water rather than the ground. 
The energy efficiency of a BHE mostly depends on the thermal conductivity of the underground rock mass. Other construction parameters also influence the energy efficiency. There are various types of BHEs, with the most typical being:

- $\quad$ single U-tube;

- multi U-tube;

- coaxial [8,9];

- helical [10,11]; and,

- $\quad$ BHE in piles [12].

BHEs can be vertically drilled. Alternatively, the BHE construction technology of Geothermal Radial Drilling (GRD) allows for directional (oblique) wells [13]. GRD provides the possibility of using the ground under buildings for thermal energy storage by the placing of boreholes. The effectiveness for various BHEs of different constructions has been compared. For instance, the effective thermal conductivity and performance in closed-loop vertical ground heat exchangers have been compared [14] and evaluated with TRTs [15], while the performances of the U-tube, concentric tube, and standing column well ground heat exchangers have been compared while using simulation [16]. Additionally, the thermal performances have been assessed for various types of underground heat exchangers [17] and for borehole heat exchangers specifically using TRTs [18]. The latter study included an analysis and comparison of interpretation methods.

BTES efficiencies in the literature consider such factors as borehole array geometry [19], heat transfer from the surroundings [20,21], grout parameters [22], freezing of underground water [23], and underground water flow. Studies that account for underground water flow include examinations of the influence of groundwater on: pile geothermal heat exchanger with cast-in spiral coils [24], closed-loop ground-source heat pump systems [25], the heat transfer in ground heat exchangers [26], the optimization of large-scale ground-coupled heat pump systems [27] and vertical closed-loop geothermal systems [28], the simulation of borehole heat exchangers [29], and the performance of geothermal heat exchangers [30]. Reference [31] describes many factors concerning coaxial BHEs.

The thermal response test (TRT) is an accurate and conventional method for the determination of the thermal properties of different cases of borehole heat exchangers [32]. A TRT is typically performed in large installations (over $100 \mathrm{~kW}$ ) for an exploration BHE. According to [33], the TRT is an economic test for a lower capacity limit of about $30 \mathrm{~kW}$. When the thermal parameters of the analyzed borehole heat exchanger are known, it is possible to establish the number of boreholes that are needed to satisfy heating and/or cooling demands.

Much work is being carried out to improve TRTs. For instance, a distributed TRT approach is described in [34]. The measuring process during a disturbed TRT (i.e., one with thermal sensors inside the BHE) affects the results. Sensors inside a BHE cause local turbulences and pressure losses, rendering the measuring unsettled/distorted. New methods for the interpretation of TRT results using statistics are described in [35,36]. The factors that are considered in a TRT are described in [37], for example, outdoor air temperature. Error analysis for a TRT is described in [38].

A TRT can be performed using various methods, e.g., the method that is described by Eskilson [39] and the computer code Earth Energy Designer (EED), which was developed following that method. Additionally, the extent of an underground thermal energy storage, i.e., the number and distribution of borehole heat exchangers, can be determined with numerical modeling, e.g., [40] or with commercial simulators [41].

Thermal response tests and mathematical modeling can also be used for determining the energy efficiency for thermal purposes of oil and gas wells, which have the potential for conversion to borehole heat exchangers [42]. This application has attracted increasing interest in recent years, especially for deep borehole heat exchangers, and it has correspondingly been subject to analysis by energy specialists in academe and industry. 
BHE modeling also needs to account for thermal stresses. Doing so is essential for large installations that are connected with thermal waters and heat recovery from enhanced geothermal systems $[43,44]$ and large BHE fields. The methods of thermal stress calculation that are used in the oil and gas industry can be applied for geothermal wells (and BHEs) [13].

In this article, we propose and verify a new method of establishing effective thermal conductivity of BHEs and assessing the usefulness of this method for utilization with thermal response tests. Existing methods provide the BHE thermal resistivity $\left(R_{b}\right)$ as a function of the time of the TRT, whereas it should be constant in time. The method that is proposed here rectifies this shortcoming. That is, it is often possible to observe a change in $R_{b}$ with time during a TRT [45]. Sometimes the change is an increase and at other times a decrease. Since the formula includes the effective thermal conductivity of the BHE $\left(\lambda_{\text {eff }}\right)$, the value of $\lambda_{\text {eff }}$ can be found, which yields a constant function $R_{b}$ with time.

The novelty of this article lies in it presenting a new enhancement to a methodology. The methodology is described in the paper and verified while using the analyses of two TRTs. The main contribution and scientific significance is that it assists efforts to interpret TRTs better, so as to avoid tests providing erroneous or problematic results. Problematic TRTs occur quite often in practice.

The proposed new approach is based on the equation for the thermal resistivity of a BHE $R_{b}$ in the function of the thermal conductivity of a rock mass $\lambda$ or effective thermal conductivity $\lambda_{\text {eff }}$, as determined on the basis of a TRT. The new methodology is based on the assumption that $R_{b}$ does not depend on the duration of the TRT, an assumption that corresponds to reality.

The basic assumption of the new approach can be expressed by the formula $R_{b}=f(t)=$ constant. The equation $R_{b}=f(t)$ can be developed into the dependence of $R_{b}=k t+b$. According to the model assumption $k t+b=$ constant, the equation is spilled if and only if $k=0$. The determination of thermal conductivity $\lambda_{x}$ and BHE thermal resistivity $R_{b}$ is reduced in this methodology to determining such a value of $\lambda_{x}$, to obtain $k=0$. Subsequently, we get $R_{b}=b$.

\section{Thermal Response Test Mathematical Background}

According to the well-established Kelvin infinite line source theory thermal response test was developed [46]. The TRT methodology is based on the partial differential equation form of the Fourier thermal conductivity equation, which describes the dynamic dependence of temperature $T$ on the distance from heat exchanger $r$ and duration of the test $t$, i.e., determines $T=T(r, t)$. The equation has the following form:

$$
\frac{\partial^{2} T}{\partial r^{2}}+\frac{1}{r} \frac{\partial T}{\partial r}=\frac{\rho c_{p}}{\lambda} \frac{\partial T}{\partial t}
$$

One method of solving such a partial differential equation involves substitution. This transforms the partial differential Equation (1) to an ordinary differential equation. Perina [47] has used this approach to describe the Theis equation in hydrogeology, which gives the pressure distribution $p=p(r, t)$. To use this approach, we let

$$
u=\frac{r^{2} \rho c_{p}}{4 t \lambda}
$$

and

$$
\rho c_{p}=\frac{\lambda}{\alpha}
$$

Subsequently, we can show that

$$
u=\frac{r^{2}}{4 \alpha t}
$$

and Equation (1) assumes the following form:

$$
\frac{\partial^{2} T}{\partial r^{2}}+\frac{1}{r} \frac{\partial T}{\partial r}=\frac{1}{\alpha} \frac{\partial T}{\partial t}
$$


Returning to the Substitution (4), we finally obtain

$$
T(r, t)=T_{0}+\frac{q}{k \pi \lambda} \int_{\substack{r^{2} \\ 4 \alpha \lambda}}^{\infty} \frac{e^{-x}}{x} d x
$$

In view of the substitution in Equation (4), and by substituting the integral in (6) with an approximate expression, we obtain

$$
T(r, t)=T_{0}+\frac{q}{4 \pi \lambda}\left[\ln \left(\frac{4 \alpha t}{r^{2}}\right)-\gamma\right]
$$

Regarding initial and boundary conditions, it is noted that the solution obtained is not numerical. Rather, it is analytical and the idea of the mathematical model of the TRT is based on an infinite linear heat source. Accordingly, we do not solve the differential equation in a finite region. The (linear) source has a length that corresponds to the borehole depth. The time of the TRT is limited (max. $100 \mathrm{~h}$ ). The initial temperature corresponds to the natural temperature distribution, as seen in Figure 1, but it is normally approximated with one initial temperature: $T_{0}$.

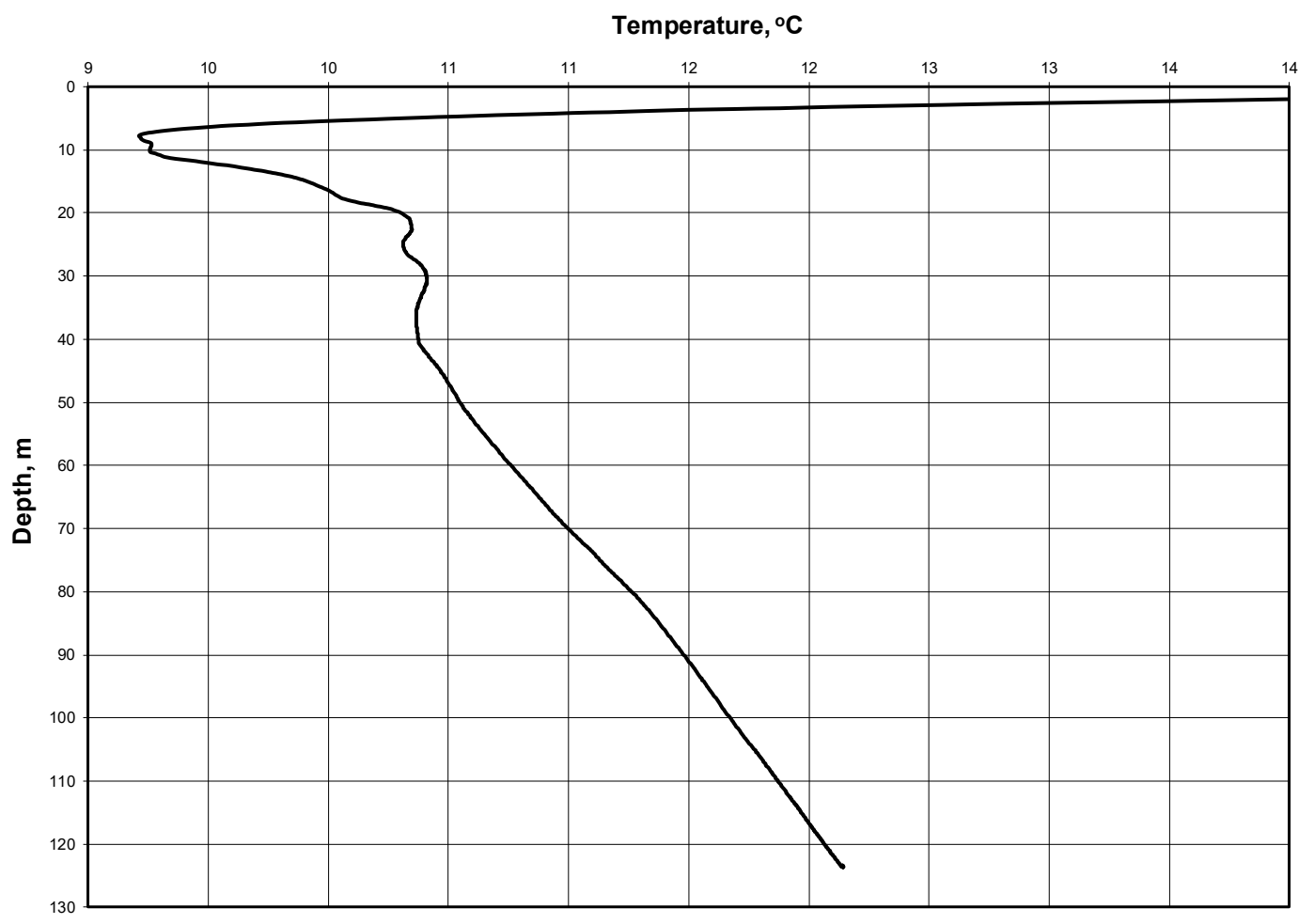

Figure 1. Natural (undisturbed) temperature profile of the BHE in Żarów.

\section{Two Thermal Response Tests}

The Thermal Response Test (TRT), which is sometimes called the Geothermal Response Test (GRT), is a suitable method in determining the effective thermal conductivity of the ground and the borehole thermal resistance (or the thermal conductivity of the borehole fill). A temperature curve is obtained, which can be evaluated by several methods. The resulting thermal conductivity is based on the total heat transport in the ground. Other effects, like convective heat transport (in permeable layers with groundwater), and further disturbances are automatically included, so it may be more

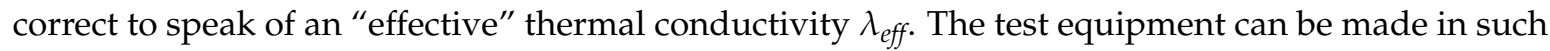
a way that it can be easily transported to the site, e.g., on a light trailer (Figure 2) [48]. In short, a TRT 
relies on forcing the closed circulation of a heat carrier that is heated with a constant heating power. The temperature change with time is analyzed.

The TRT involves introducing and collecting energy from a borehole heat exchanger (Figure 2). During the tests, the heat carrier is most frequently heated at a constant heating power $P$, which is measured, and the temperatures $T_{1}$ and $T_{2}$ are then recorded. The heating power is maintained by switching the heaters on and off. The automation system takes into account the variability with the temperature of the heat carrier density $\rho$ and the specific heat at constant pressure $c_{p}$.

This section describes two actual thermal response tests. The Laboratory of Geoenergetics, Faculty of Drilling, Oil, and Gas, AGH University of Science and Technology in Krakow, Poland performed the tests and analyses [49,50]. The tests were carried out to illustrate and compare the results from the old and new methods of TRT interpretation.

For the sake of interpretation, it is noted that the TRT was performed for a borehole heat exchanger, the geological profile of which is presented in Table 1. The first test was performed in Żarów (Dolnoślaskie Region, Poland) in 2011. The average heating power during the test was $P=5920$ $\mathrm{W}$ and the volumetric flow rate of the carrier was $16 \mathrm{dm}^{3} \cdot \mathrm{min}^{-1}$ (Figure 3a). The control of the volume value of the heat carrier volumetric flow rate was carried out with a rotary (windmill) flowmeter with an accuracy of $0.25 \mathrm{dm}^{3}$ per one impulse. The flow measurements have the task of only visual control of the correctness of the TRT execution, where the relationship $Q=$ const should be satisfied. Similarly, for the value of heating power $\mathrm{P}$, which is calculated on the basis of temperature measurements from the dependence $P=Q \rho c \Delta T$, the visual relationship (Figure 3a) should be observed during the entire test to ensure $P=$ const.

The borehole heat exchanger is $H=120 \mathrm{~m}$ deep, so the heat exchange per unit of depth is $q=49.34$ $\mathrm{W} \cdot \mathrm{m}^{-1}$. In the linear heat source model, the unit heating power is assumed to be uniform. A constant temperature is also assumed in the model for the heat carrier and the ground. Table 2 presents the design of the borehole heat exchanger.

A second TRT was performed in the BHE at the Laboratory of Geoenergetics in the university, where the lithological profile is as described in Table 3. 


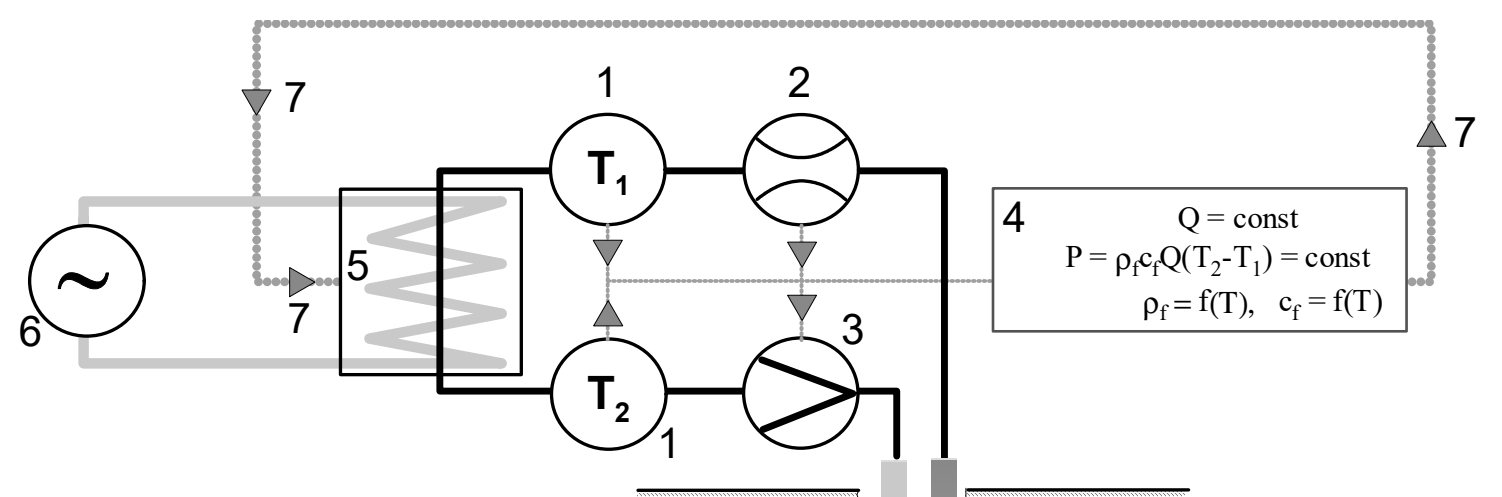

8

Figure 2. Schematic of thermal response test devices and operation. Legend: 1-thermometer, with absolute error $0.1{ }^{\circ} \mathrm{C}$, 2-flowmeter, 3-pump, 4-control computer (stabilisation of thermal power and record the data), 5-set of heaters, 6-current source, 7-heater control signal, 8-borehole heat exchanger, $Q$-flow rate of heat carrier, $P$-heat flow rate (power), $T_{1}$-temperature of heat carrier (outflow from borehole heat exchangers (BHE)), $\mathrm{T}_{1}$-temperature of heat carrier (inflow to BHE), $\rho_{f}=\mathrm{f}(\mathrm{T})$-density of heat carrier as a function of temperature, and $c_{f}=\mathrm{f}(T)$-specific heat of heat carrier as a function of temperature. 


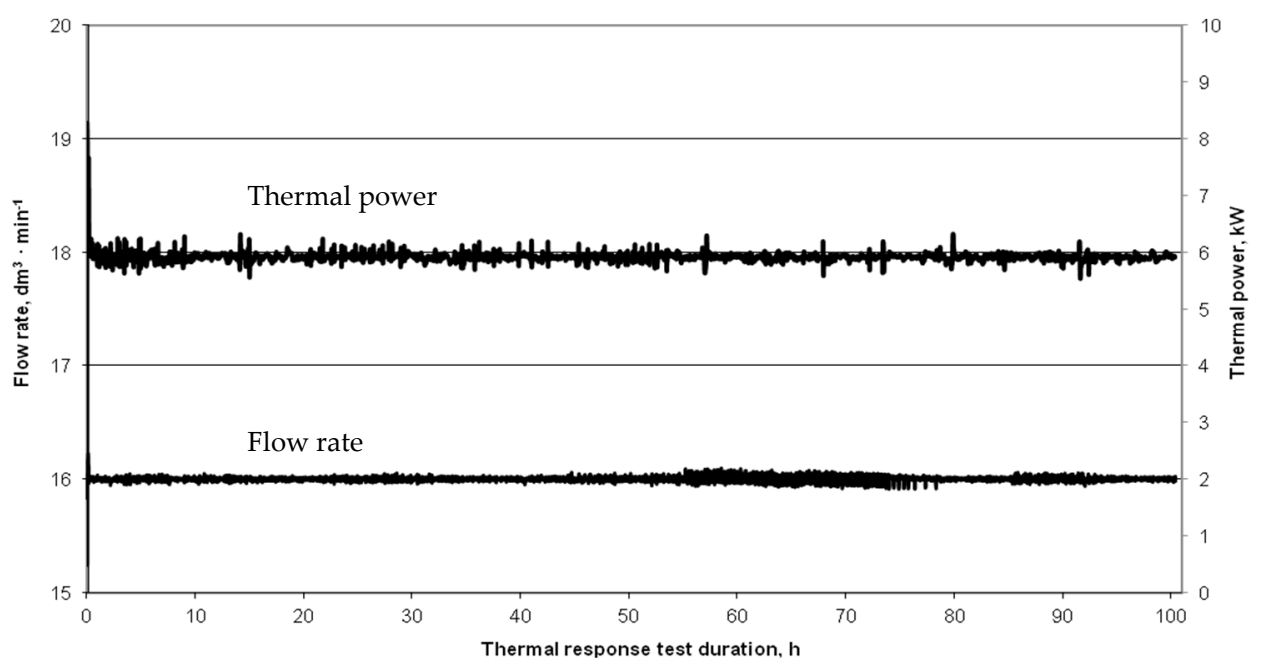

(a)

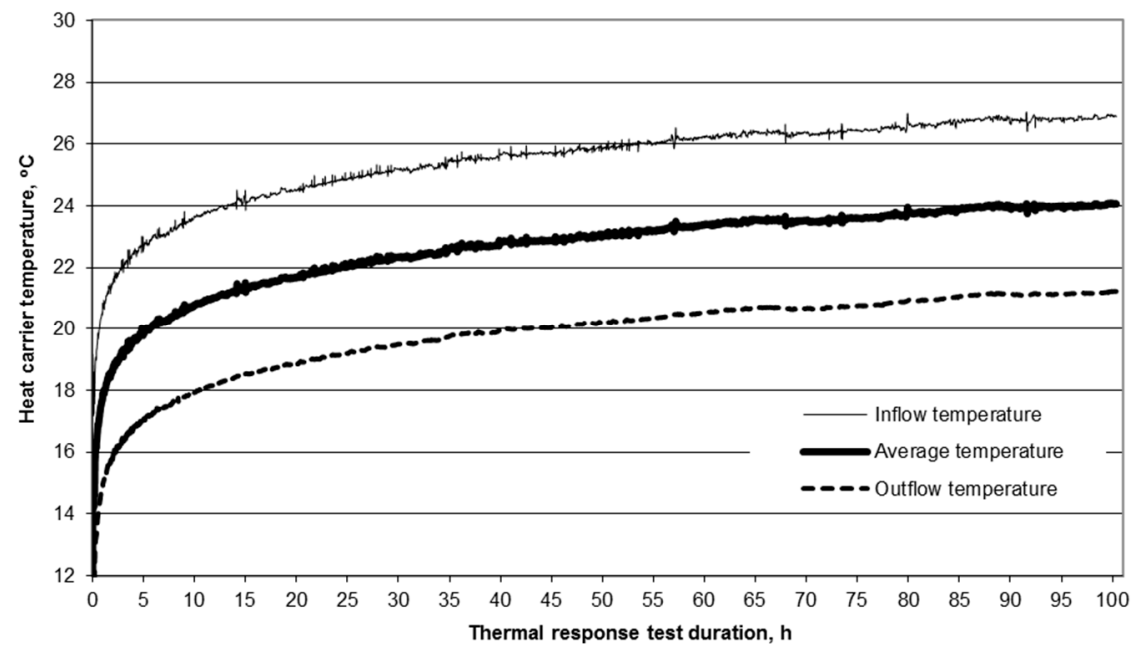

(b)

Figure 3. (a) Variation during Thermal Response Test (TRT) of heating power and carrier volumetric flow rate with time; (b) results of thermal response test. 
Table 1. Lithological profile of borehole in Żarów, Poland.

\begin{tabular}{|c|c|c|c|c|c|c|}
\hline Lithology & Top, m Below Surface & Bottom, m Below Surface & Thickness, $\mathrm{m}$ & $\begin{array}{l}\text { Thermal Conductivity, } \\
\mathrm{W} \cdot \mathrm{m}^{-1} \cdot \mathrm{K}^{-1}\end{array}$ & $\begin{array}{c}\text { Volumetric Thermal } \\
\text { Capacity, } \mathrm{MJ} \cdot \mathrm{m}^{-3} \cdot \mathrm{K}^{-1}\end{array}$ & $\begin{array}{c}\text { Thermal Diffusivity, } \\
10^{-6} \cdot \mathrm{m}^{2} \cdot \mathrm{s}^{-1}\end{array}$ \\
\hline Soil & 0.0 & 0.3 & 0.3 & 0.80 & 2.00 & 0.40 \\
\hline Clayey sandy gravel & 0.3 & 6.0 & 5.7 & 1.50 & 1.90 & 0.79 \\
\hline Sandy gravel & 6.0 & 14.0 & 8.0 & 1.50 & 2.10 & 0.71 \\
\hline Gravel & 14.0 & 16.0 & 2.0 & 1.80 & 2.10 & 0.86 \\
\hline Clay & 16.0 & 18.0 & 2.0 & 1.50 & 2.00 & 0.75 \\
\hline Silt & 18.0 & 20.0 & 2.0 & 1.20 & 1.90 & 0.63 \\
\hline Brown coal & 20.0 & 22.0 & 2.0 & 0.30 & 1.80 & 0.17 \\
\hline Medium sand & 22.0 & 36.0 & 14.0 & 2.10 & 2.00 & 1.05 \\
\hline Coarse sand and gravel & 36.0 & 87.0 & 51.0 & 2.00 & 2.10 & 0.95 \\
\hline Granite detritus & 87.0 & 90.0 & 3.0 & 3.00 & 2.10 & 1.43 \\
\hline \multirow[t]{2}{*}{ Metamorphic rocks-amphibiolites } & 90.0 & 120.0 & 30.0 & 2.90 & 2.60 & 1.12 \\
\hline & Weighted mean & & & 2.15 & 2.17 & 0.97 \\
\hline
\end{tabular}

Table 2. Design of borehole heat exchanger in Żarów and at Laboratory of Geoenergetics, Faculty of Drilling, Oil, and Gas, AGH University of Science and Technology in Krakow [51].

$\begin{array}{lll}\text { No. } & \text { Parameter } & \text { Value for BHE in Żarów } \\ \text { Borehole diameter } \mathrm{D}_{\mathrm{o}} \text { (diameter of drilling bit) interval } 90-120 \mathrm{~m} \text { with diameter } 125 \mathrm{~mm} \\ \text { (on average } 176 \mathrm{~mm})\end{array}$


Table 2. Cont

\begin{tabular}{|c|c|c|c|c|}
\hline No. & Parameter & Value for BHE in Żarów & Value for BHE of Laboratory & Schematic \\
\hline 3 & Depth of borehole, $\mathrm{H}_{\mathrm{b}}$ & $121 \mathrm{~m}$ & $78 \mathrm{~m}$ & - \\
\hline 4 & Depth of deposition of borehole tubes, $\mathrm{H}$ & $120 \mathrm{~m}$ & $78 \mathrm{~m}$ & - \\
\hline 5 & Distance between axes of borehole tubes $\mathrm{k}$ & $50 \mathrm{~mm}$ & $80 \mathrm{~mm}$ & \\
\hline 6 & Type of material used for sealing BHE tubes & $\begin{array}{c}\text { Gravel (2-8 mm, } \\
\left.\text { with } \lambda=1.8 \mathrm{Wm}^{-1} \mathrm{~K}^{-1} \text { assumed }\right)\end{array}$ & $\begin{array}{c}\text { Gravel (with } \\
\lambda_{g}=1.8 \mathrm{Wm}^{-1} \mathrm{~K}^{-1} \text { ) }\end{array}$ & \\
\hline 7 & Outer diameter of BHE tubes, $\mathrm{d}_{\mathrm{z}}$ & $40 \mathrm{~mm}$ & $40 \mathrm{~mm}$ & \\
\hline
\end{tabular}


Table 2. Cont.

\begin{tabular}{|c|c|c|c|c|}
\hline No. & Parameter & Value for BHE in Żarów & Value for BHE of Laboratory & Schematic \\
\hline 8 & Thickness of BHE tube wall, b & $3.7 \mathrm{~mm}$ & $2.4 \mathrm{~mm}$ & \\
\hline 9 & Material of borehole tubes & $\begin{array}{l}\text { Polyethylene PE } 100 \\
\left(\lambda=0.42 \mathrm{Wm}^{-1} \mathrm{~K}^{-1}\right)\end{array}$ & $\begin{array}{l}\text { Polyethylene PE } 100 \\
\left(\lambda=0.42 \mathrm{Wm}^{-1} \mathrm{~K}^{-1}\right)\end{array}$ & \\
\hline
\end{tabular}

Table 3. Lithological profile of borehole at AGH-UST in Krakow, Poland [51].

\begin{tabular}{|c|c|c|c|c|c|c|}
\hline Lithology & Top, m Below Surface & Bottom, m Below Surface & Thickness, m & $\begin{array}{l}\text { Thermal Conductivity, } \\
\mathrm{W} \cdot \mathrm{m}^{-1} \cdot \mathrm{K}^{-1}\end{array}$ & $\begin{array}{c}\text { Volumetric Thermal } \\
\text { Capacity, } \mathrm{MJ} \cdot \mathrm{m}^{-3} \cdot \mathrm{K}^{-1}\end{array}$ & $\begin{array}{l}\text { Thermal Diffusivity, } \\
\quad 10^{-6} \cdot \mathrm{m}^{2} \cdot \mathrm{s}^{-1}\end{array}$ \\
\hline $\begin{array}{l}\text { Anthropogenic (dark grey } \\
\text { embankment with debris) }\end{array}$ & 1.8 & 2.2 & 0.4 & 1.60 & 2.00 & 0.80 \\
\hline Alluvion (grey soil) & 2.2 & 2.6 & 0.4 & 1.60 & 2.20 & 0.73 \\
\hline $\begin{array}{c}\text { Fine sand, dusty and slightly } \\
\text { clayey }\end{array}$ & 2.6 & 4.0 & 1.4 & 1.00 & 2.00 & 0.50 \\
\hline Fine sand & 4.0 & 6.0 & 2.0 & 1.20 & 2.50 & 0.48 \\
\hline Sandy gravel and gravel & 6.0 & 15.0 & 9.0 & 1.80 & 2.40 & 0.75 \\
\hline Grey silt & 15.0 & 30.0 & 15.0 & 2.20 & 2.30 & 0.96 \\
\hline \multirow[t]{2}{*}{ Grey silt shale } & 30.0 & 78.0 & 48.0 & 2.10 & 2.30 & 0.91 \\
\hline & Weighted mean & & & 2.04 & 2.31 & 0.88 \\
\hline
\end{tabular}


The values of $D_{o}, d_{z}, H_{b}, b$, and $H$ (in Equation (8)) in Table 2 were provided by a company making a BHE without any data on measurement accuracy. The value of $\lambda_{g}$ comes from the literature [51].

Figure $3 \mathrm{~b}$ presents the curves illustrating the data during the TRT test, where the dependence on the duration of the test is observed. The average thermal conductivity that is assumed for rocks of $2.15 \mathrm{~W} \cdot \mathrm{m}^{-1} \cdot \mathrm{K}^{-1}$ is based on data in the literature [51], as is the average volumetric specific heat of rocks in the profile of $2.17 \mathrm{MJ} \cdot \mathrm{m}^{-3} \cdot \mathrm{K}^{-1}$ [52,53]. A $35 \%$ propylene glycol solution is used as the heat carrier. At $20^{\circ} \mathrm{C}$, the specific heat of the carrier is $3810 \mathrm{~J} \cdot \mathrm{kg}^{-1} \cdot \mathrm{K}^{-1}$ and its density is $1028 \mathrm{~kg} \cdot \mathrm{m}^{-3}$.

The average temperature of the rock mass is determined on the basis of the heat carrier circulation, without heating (i.e., before the TRT heating phase begins). The return flow temperature is $11.1^{\circ} \mathrm{C}$ and the mean measured air temperature is $16.1{ }^{\circ} \mathrm{C}$. The mean natural temperature in the borehole can also be determined on the basis of temperature logging [54]. The mean temperature of the rock mass, based on the temperature profile (Figure 1), is $11.00^{\circ} \mathrm{C}$. The NIMO-T (Non-wired Immersible Measuring Object for Temperature) was used for temperature profiling in BHE. The relative error of the temperature measurement was $0.0015^{\circ} \mathrm{C}$ and the absolute error was $0.1^{\circ} \mathrm{C}$ [54].

The thermal diffusivity $\alpha=0.97 \cdot 10^{-6} \mathrm{~m}^{2} \cdot \mathrm{s}^{-1}$ is calculated using data from the literature [51] and Equation (3).

The mean temperature of the heat carrier flowing into the $\mathrm{BHE}$ during the test is $25.48^{\circ} \mathrm{C}$ and the mean return flow temperature is $19.82^{\circ} \mathrm{C}$. Thus, the mean temperature difference is $5.67^{\circ} \mathrm{C}$ and the mean temperature of the heat carrier is $22.65^{\circ} \mathrm{C}$.

Figure 4 shows the characteristic times that are used for the interpretation of TRT results. There, the points are denoted, as follows: $t_{0}$ the beginning of heating phase of the test (heaters on), $t_{1}$ the slope point of the curve (time of the first complete circulation loop of the heat carrier), $t_{2}$ the time corresponding to $\mathrm{t}=5 r_{o}^{2} \alpha^{-1}, t_{3}$ the time corresponding to $\mathrm{t}=20 r_{o}^{2} \alpha^{-1}, t_{4}$ the half-time of the heating phase of the test, and $t_{5}$ the end of the heating phase of the test (heaters off).

The following values were obtained during the test: $t_{0}=0, t_{1}=480 \mathrm{~s}(0.13 \mathrm{~h}), t_{2}=46348 \mathrm{~s}(12.87 \mathrm{~h})$, $t_{3}=185391 \mathrm{~s}(51.50 \mathrm{~h}), t_{4}=180660 \mathrm{~s}(50.18 \mathrm{~h})$, and $t_{5}=361320 \mathrm{~s}(100.37 \mathrm{~h})$. Linear regression analysis is used for determining coefficients of line slope in the semi-logarithmic system (log $t$ ) for the following time intervals:

- from $t_{0}$ to $t_{5}$

- from $t_{1}$ to $t_{5}$

- from $t_{2}$ to $t_{5}$

- from $t_{0}$ to $t_{2}$

- from $t_{0}$ to $t_{3}$

- from $t_{2}$ to $t_{3}$

- from $t_{1}$ to $t_{4}$

- $\quad$ from $t_{3}$ to $t_{5}$.

The values of the slope coefficient $k$ and the effective thermal conductivity $\lambda_{\text {eff }}$ are calculated on the basis of Equation (7), as follows:

$$
\lambda_{e f f}=\frac{P}{4 \pi H k}=\frac{q}{4 \pi k}
$$

Table 4 lists the results, including the average values of the BHE thermal resistivity $R_{b}$ and values for various data intervals. The value of $R_{b}$ is calculated, as follows:

$$
R_{b}=\frac{1}{q}\left[T_{a v}(t)-T_{0}\right]-\frac{1}{4 \pi \lambda}\left[\ln \frac{4 \alpha t}{r_{o}^{2}}-\gamma\right]
$$

Here, values for $\lambda$ can be taken from the literature $\left(\lambda=2.15 \mathrm{~W} \cdot \mathrm{m}^{-1} \cdot \mathrm{K}^{-1}\right.$ from Table 1$)$ or calculated with Equation (7). 
In Table 5, the TRT results are shown for a BHE belonging to the Laboratory of Geoenergetics, Faculty of Drilling, Oil, and Gas AGH-University of Science and Technology for a heat carrier volumetric flow rate of $12 \mathrm{dm}^{3} \cdot \mathrm{min}^{-1}$ and heating power $P=4000 \mathrm{~W}$. The lithological profile of the borehole was described earlier (Table 5), as was the design of the borehole heat exchanger (Table 2).

The correlation coefficient for two TRTs was calculated. It concerned the temperatures dependence of the heat carrier and the duration of TRT. In both cases, the correlation coefficient had a higher value than 0.925 .

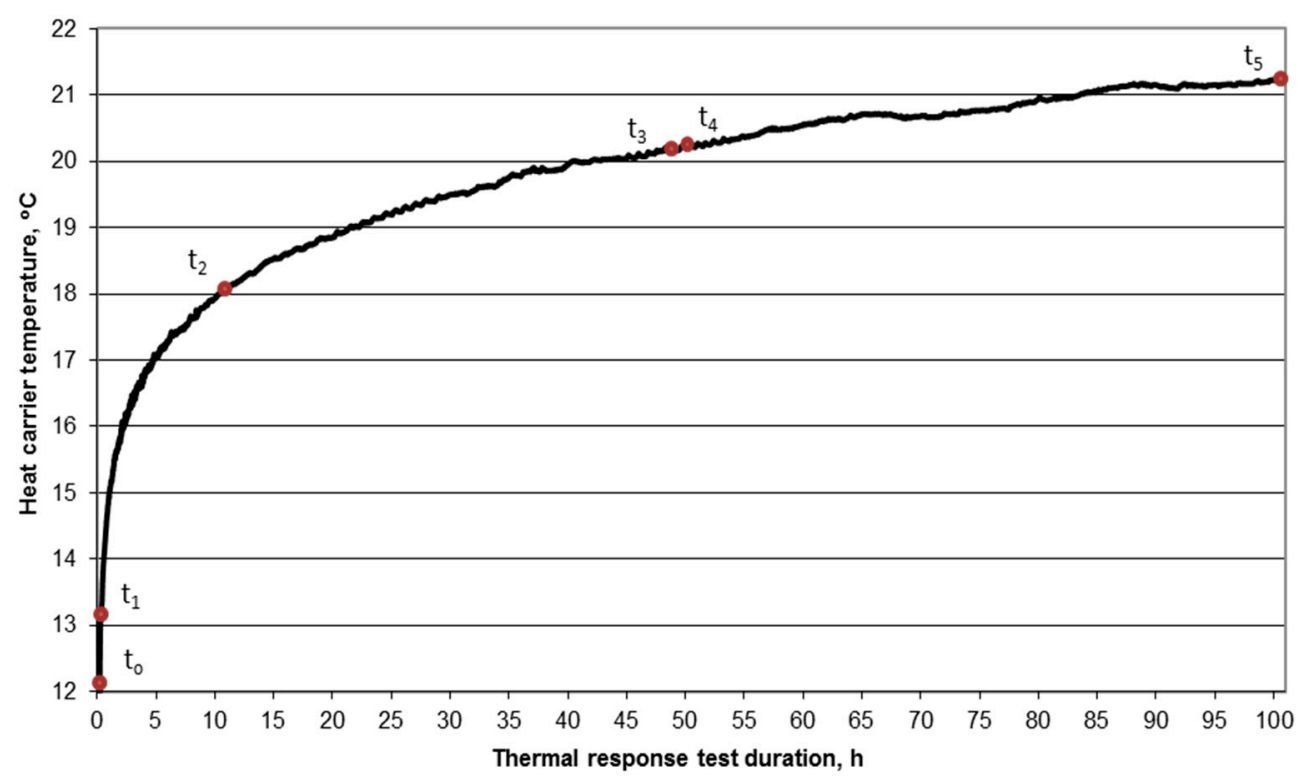

(a)

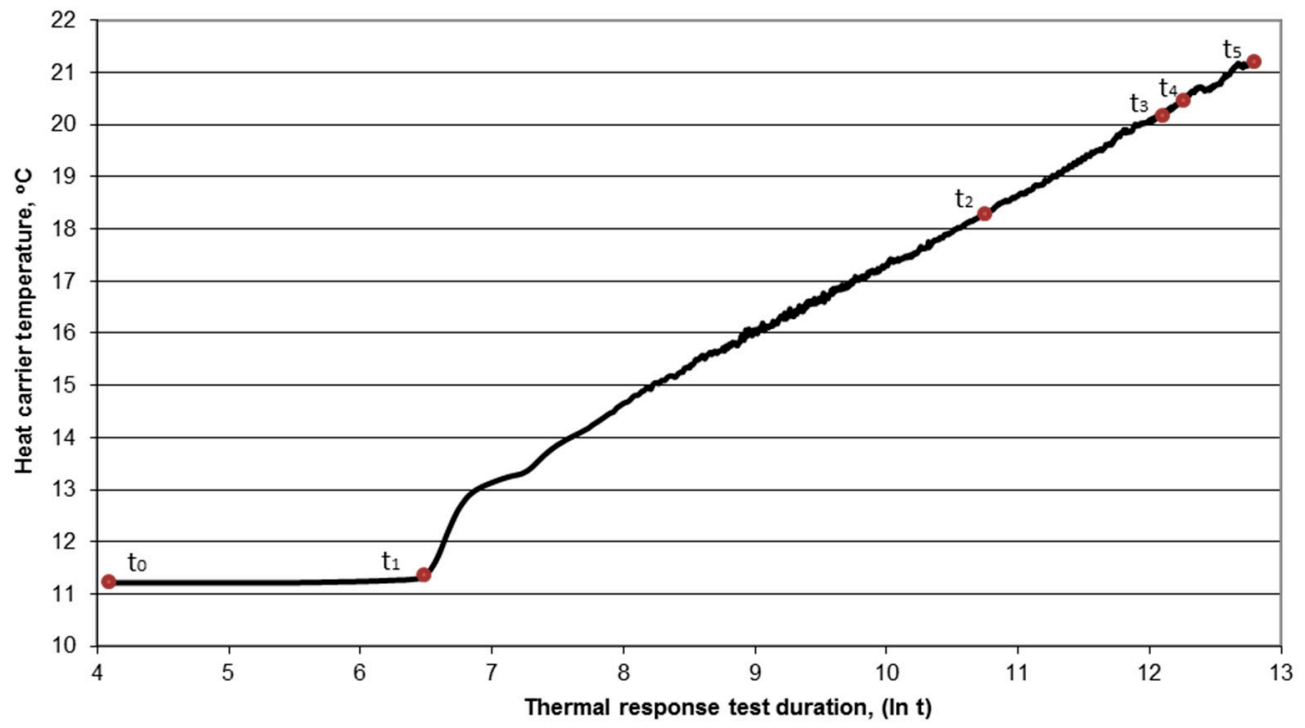

(b)

Figure 4. Variation of temperature of heat carrier flowing out of BHE with (a) time and (b) logarithm of time, showing key characteristic times. 
Table 4. Thermal resistivity $R_{b}$ and effective thermal conductivity $\lambda_{\text {eff }}$ of BHE, as determined for various data ranges (TRT in Żarów).

\begin{tabular}{|c|c|c|c|c|c|c|c|c|}
\hline Data & $\begin{array}{c}\text { Full Range of } \\
\text { Data }\end{array}$ & $\begin{array}{l}\text { From Slope to } \\
\text { End of TRT }\end{array}$ & $\begin{array}{c}\text { From } t=5 r_{o}^{2} \alpha^{-1} \\
\text { to End of TRT }\end{array}$ & $\begin{array}{l}\text { From Beginning } \\
\text { to } t=5 r_{o}^{2} \alpha^{-1}\end{array}$ & $\begin{array}{l}\text { From Beginning } \\
\text { to } t=20 r_{o}^{2} \alpha^{-1}\end{array}$ & $\begin{array}{l}\text { From } t=5 r_{o}^{2} \alpha^{-1} \\
\text { to } t=20 r_{o}^{2} \alpha^{-1}\end{array}$ & $\begin{array}{l}\text { From Slope to } \\
\text { Half Time of Full } \\
\text { Range of Data }\end{array}$ & $\begin{array}{c}\text { From } t=20 r_{o}^{2} \alpha^{-1} \\
\text { to End of TRT }\end{array}$ \\
\hline & $t_{0}$ to $t_{5}$ & $t_{1}$ to $t_{5}$ & $t_{2}$ to $t_{5}$ & $t_{0}$ to $t_{2}$ & $t_{0}$ to $t_{3}$ & $t_{2}$ to $t_{3}$ & $t_{1}$ to $t_{4}$ & $t_{3}$ to $t_{5}$ \\
\hline $\begin{array}{c}R_{b} \text { for } \lambda_{\text {eff according to the }} \\
\text { literature }(\text { Equation }(9)) \\
\mathrm{m} \cdot \mathrm{K} \cdot \mathrm{W}^{-1}\end{array}$ & 0.1094 & 0.1093 & 0.1069 & 0.1265 & 0.1144 & 0.1103 & 0.1144 & 0.1041 \\
\hline $\begin{array}{c}\text { Relative change of } R_{b} \text { with } \\
\text { respect to full } \\
\text { measurement range, \% }\end{array}$ & 0.00 & 0.09 & 2.29 & -15.63 & -4.57 & -0.82 & -4.57 & 4.84 \\
\hline $\begin{array}{l}R_{b} \text { for } \lambda_{\text {eff }} \text { according to TRT } \\
\text { (Equation (9)), } \mathrm{m} \cdot \mathrm{K} \cdot \mathrm{W}^{-1}\end{array}$ & 0.1303 & 0.1303 & 0.1303 & 0.1308 & 0.1299 & 0.1296 & 0.1299 & 0.1307 \\
\hline $\begin{array}{c}\text { Relative change of } R_{b} \text { with } \\
\text { respect to full } \\
\text { measurement range, \% }\end{array}$ & 0.00 & 0.00 & 0.00 & -0.38 & 0.31 & $\underline{0.54}$ & 0.31 & -0.31 \\
\hline $\begin{array}{l}\text { Effective thermal } \\
\text { conductivity } \lambda_{\text {eff }} \text { in BHE } \\
\text { (Equation }(8) \text { ) for } \\
\text { temperature of inflow heat } \\
\text { carrier, } \mathrm{W} \cdot \mathrm{m}^{-1} \cdot \mathrm{K}^{-1}\end{array}$ & 2.8132 & 2.7993 & 2.6959 & 2.9879 & 2.8821 & 2.718 & 2.8633 & 2.7749 \\
\hline $\begin{array}{l}\text { Effective thermal } \\
\text { conductivity } \lambda_{\text {eff }} \text { in } \mathrm{BHE} \\
\text { (Equation }(8)) \text { for } \\
\text { temperature of outflow } \\
\text { heat carrier, } \mathrm{W} \cdot \mathrm{m}^{-1} \cdot \mathrm{K}^{-1}\end{array}$ & 2.8022 & 2.787 & 2.697 & 2.943 & 2.8619 & 2.7156 & 2.8389 & 2.7472 \\
\hline $\begin{array}{c}\text { Effective thermal } \\
\text { conductivity } \lambda_{\text {eff }} \text { in } \mathrm{BHE} \\
\text { (Equation }(8) \text { ) for mean } \\
\text { temperature of heat carrier, } \\
\mathrm{W} \cdot \mathrm{m}^{-1} \cdot \mathrm{K}^{-1}\end{array}$ & 2.8077 & 2.7931 & 2.6965 & 2.9653 & 2.872 & 2.7168 & 2.8511 & 2.761 \\
\hline $\begin{array}{l}\text { Relative change of } \lambda_{\text {eff }} \text { with } \\
\text { respect to full } \\
\text { measurement range, \% }\end{array}$ & 0.00 & 0.52 & 3.96 & -5.61 & -2.29 & 3.24 & -1.55 & 1.66 \\
\hline
\end{tabular}


Table 5. Thermal resistivity $R_{b}$ and effective thermal conductivity $\lambda_{\text {eff }}$ of BHE, as determined for various data intervals (TRT at Laboratory of Geoenergetics).

\begin{tabular}{|c|c|c|c|c|c|c|c|c|}
\hline Data & $\begin{array}{c}\text { Full Range of } \\
\text { Data }\end{array}$ & $\begin{array}{l}\text { From Slope to } \\
\text { End of TRT }\end{array}$ & $\begin{array}{l}\text { From } t=5 r_{o}^{2} \alpha^{-1} \\
\text { to End of TRT }\end{array}$ & $\begin{array}{l}\text { From Beginning } \\
\text { to } t=5 r_{o}^{2} \alpha^{-1}\end{array}$ & $\begin{array}{l}\text { From Beginning } \\
\text { to } t=20 r_{o}^{2} \alpha^{-1}\end{array}$ & $\begin{array}{l}\text { From } t=5 r_{o}^{2} \alpha^{-1} \\
\text { to } t=20 r_{o}^{2} \alpha^{-1}\end{array}$ & $\begin{array}{l}\text { From Slope to } \\
\text { Half Time of Full } \\
\text { Range Of Data }\end{array}$ & $\begin{array}{c}\text { From } t=20 r_{o}^{2} \alpha^{-1} \\
\text { to End of TRT }\end{array}$ \\
\hline & $t_{0}$ to $t_{5}$ & $t_{1}$ to $t_{5}$ & $t_{2}$ to $t_{5}$ & $t_{0}$ to $t_{2}$ & $t_{0}$ to $t_{3}$ & $t_{2}$ to $t_{3}$ & $t_{1}$ to $t_{4}$ & $t_{3}$ to $t_{5}$ \\
\hline $\begin{array}{c}R_{b} \text { for } \lambda_{\text {eff according to the }} \\
\text { literature (Equation (9)) } \\
\mathrm{m} \cdot \mathrm{K} \cdot \mathrm{W}^{-1}\end{array}$ & 0.1383 & 0.1382 & 0.1389 & 0.1313 & 0.1364 & 0.1382 & 0.1371 & 0.1391 \\
\hline $\begin{array}{c}\text { Relative change of } R_{b} \text { with } \\
\text { respect to full } \\
\text { measurement range, \% }\end{array}$ & 0.00 & 0.07 & -0.43 & $\underline{5.06}$ & 1.37 & 0.07 & 0.87 & -0.58 \\
\hline $\begin{array}{l}R_{b} \text { for } \lambda_{\text {eff }} \text { according to TRT } \\
\text { (Equation (9)), } \mathrm{m} \cdot \mathrm{K} \cdot \mathrm{W}^{-1}\end{array}$ & 0.1276 & 0.1274 & 0.1274 & 0.1299 & 0.1299 & 0.1299 & 0.1289 & 0.1264 \\
\hline $\begin{array}{c}\text { Relative change of } R_{b} \text { with } \\
\text { respect to full } \\
\text { measurement range, \% }\end{array}$ & 0.00 & 0.16 & 0.16 & $\underline{-1.80}$ & $\underline{-1.80}$ & $\underline{-1.80}$ & -1.02 & 0.94 \\
\hline $\begin{array}{l}\text { Effective thermal } \\
\text { conductivity } \lambda_{\text {eff }} \text { in } \mathrm{BHE} \\
\text { (Equation }(8)) \text { for } \\
\text { temperature of inflow heat } \\
\text { carrier, } \mathrm{W} \cdot \mathrm{m}^{-1} \cdot \mathrm{K}^{-1}\end{array}$ & 1.9659 & 1.9296 & 2.0082 & 2.2368 & 1.9496 & 1.8620 & 1.8779 & 2.1439 \\
\hline $\begin{array}{l}\text { Effective thermal } \\
\text { conductivity } \lambda_{\text {eff }} \text { in } \mathrm{BHE} \\
(\text { Equation }(8)) \text { for } \\
\text { temperature of outflow } \\
\text { heat carrier, } \mathrm{W} \cdot \mathrm{m}^{-1} \cdot \mathrm{K}^{-1}\end{array}$ & 1.9750 & 1.9275 & 2.0079 & 2.3576 & 1.9754 & 1.8613 & 1.8745 & 2.1442 \\
\hline $\begin{array}{c}\text { Effective thermal } \\
\text { conductivity } \lambda_{\text {eff in } \mathrm{BHE}} \\
\text { (Equation }(8) \text { for mean } \\
\text { temperature of heat carrier, } \\
\mathrm{W} \cdot \mathrm{m}^{-1} \cdot \mathrm{K}^{-1}\end{array}$ & 1.9705 & 1.9286 & 2.0080 & 2.2956 & 1.9624 & 1.8616 & 1.8762 & 2.1440 \\
\hline $\begin{array}{l}\text { Relative change of } \lambda_{\text {eff }} \text { with } \\
\text { respect to full } \\
\text { measurement range, } \%\end{array}$ & 0.00 & 2.13 & -1.90 & -16.50 & 0.41 & 5.53 & 4.79 & -8.80 \\
\hline
\end{tabular}




\section{A New Way of Determining Parameters from TRTs}

Although the test (Figure 3b) was carried out almost ideally, there are discrepancies in the BHE thermal conductivity and thermal resistivity values. These discrepancies stem from the different ranges of data that are assumed for the analyses. Therefore, a new way of determining the parameters $\lambda_{\text {eff }}$ and $R_{b}$ is proposed.

Figure 5 presents a graph showing the dependence of BHE thermal resistivity on test duration. The curves for $R_{b 1}$ and $R_{b 4}$ are more 'linear' in Figure 5 than the curves for $R_{b 2}, R_{b 3}$, and $R_{b 5}$. Both of the curves only differ in the value of $\lambda$ from Equation (8).

The proposed approach involves determining a value of $\lambda$ for which linear regression that is based on $R_{b}=f(t)$ assumes the form of a function $R_{b}=k t+b$ with a slope coefficient $k$ of zero. The task of determining $\lambda$ and $R_{b}$ values reduces to finding a $\lambda$ value, for which $k=0$, after which we have $R_{b}=b$. For the TRT that was performed in Żarów, we determined the following pairs of values meeting this requirement: $\lambda_{\text {eff }}=2.77 \mathrm{~W} \cdot \mathrm{m}^{-1} \cdot \mathrm{K}^{-1}$ and $R_{b}=0.129 \mathrm{~m} \cdot \mathrm{K} \cdot \mathrm{W}^{-1}$. This contrasts with the values obtained with the traditional method of $\lambda=2.81 \mathrm{~W} \cdot \mathrm{m}^{-1} \cdot \mathrm{K}^{-1}$ and $R_{b}=0.130 \mathrm{~m} \cdot \mathrm{K} \cdot \mathrm{W}^{-1}$.

For the TRT performed at the BHE of the Laboratory of Geoenergetics, we find $\lambda=1.98$ $\mathrm{W} \cdot \mathrm{m}^{-1} \cdot \mathrm{K}^{-1}$ and $R_{b}=0.134 \mathrm{~m} \cdot \mathrm{K} \cdot \mathrm{W}^{-1}$ (whereas with the traditional method $\lambda=1.97 \mathrm{~W} \cdot \mathrm{m}^{-1} \cdot \mathrm{K}^{-1}$ and $R_{b}=0.128 \mathrm{~m} \cdot \mathrm{K} \cdot \mathrm{W}^{-1}$ ).

Figure 5 shows the relation of $R_{b}$ with time from the TRT for the test in Żarów. The curves of $R_{b}=f(t)$ only vary due to the value of $\lambda$ in Equation (9). The waveforms represent the following:

- $\quad R_{b 1}$-graph of BHE thermal resistance vs. time for the conductivity $\lambda_{\text {eff }}$ calculated for data from a time equal $5 r_{0}^{2} \cdot \alpha^{-1}$ to the end of the heating phase of TRT $\left(\lambda_{\text {eff }}=2.70 \mathrm{~W} \cdot \mathrm{m}^{-1} \cdot \mathrm{K}^{-1}\right)$

- $\quad R_{b 2}$-graph of $\mathrm{BHE}$ thermal resistance vs. time for the conductivity $\lambda=125 \% \lambda_{\text {eff }}$ $\left(\lambda=3.37 \mathrm{~W} \cdot \mathrm{m}^{-1} \cdot \mathrm{K}^{-1}\right)$;

- $\quad R_{b 3}$-graph of BHE thermal resistance vs. time for the conductivity $\lambda=75 \% \lambda_{\text {eff }}$ $\left(\lambda=2.03 \mathrm{~W} \cdot \mathrm{m}^{-1} \cdot \mathrm{K}^{-1}\right)$;

- $\quad R_{b 4}$-graph of BHE thermal resistance vs. time for the conductivity when linear regression yields a constant function (for which $k=0$ in the function $R_{b}=k t+b$ ), according to the new method described above $\left(\lambda=2.80 \mathrm{~W} \cdot \mathrm{m}^{-1} \cdot \mathrm{K}^{-1}\right)$; and,

- $\quad R_{b 5}$-graph of BHE thermal resistance vs. time for the conductivity based on data in the literature, as in Table $1\left(\lambda=2.15 \mathrm{~W} \cdot \mathrm{m}^{-1} \cdot \mathrm{K}^{-1}\right)$.

The values of $R_{b}$ and $\lambda_{\text {eff }}$ for various time intervals calculated based on the new methodology are listed in the Table 6 for the TRT at Żarów and in Table 7 for the TRT at the Laboratory of Geoenergetics. 
Table 6. BHE thermal resistivity $R_{b}$ and effective thermal conductivity $\lambda_{\text {eff, }}$ determined using the new method for various data intervals (for TRT in Żarów).

\begin{tabular}{|c|c|c|c|c|c|c|c|c|}
\hline Data & $\begin{array}{l}\text { Full Range } \\
\text { of Data }\end{array}$ & $\begin{array}{l}\text { From Slope to } \\
\text { End of TRT }\end{array}$ & $\begin{array}{l}\text { From } t=5 r_{o}^{2} \alpha^{-1} \\
\text { to End of TRT }\end{array}$ & $\begin{array}{l}\text { From Beginning } \\
\text { to } t=5 r_{o}^{2} \alpha^{-1}\end{array}$ & $\begin{array}{l}\text { From Beginning } \\
\text { to } t=20 r_{o}^{2} \alpha^{-1}\end{array}$ & $\begin{array}{l}\text { From } t=5 r_{o}^{2} \alpha^{-1} \\
\text { to } t=20 r_{o}^{2} \alpha^{-1}\end{array}$ & $\begin{array}{l}\text { From Slope to } \\
\text { Half Time of Full } \\
\text { Range of Data }\end{array}$ & $\begin{array}{l}\text { From } t=20 r_{o}^{2} \alpha^{-1} \\
\text { to End of TRT }\end{array}$ \\
\hline & $t_{0}$ to $t_{5}$ & $t_{1}$ to $t_{5}$ & $t_{2}$ to $t_{5}$ & $t_{0}$ to $t_{2}$ & $t_{0}$ to $t_{3}$ & $t_{2}$ to $t_{3}$ & $t_{1}$ to $t_{4}$ & $t_{3}$ to $t_{5}$ \\
\hline $\begin{array}{c}R_{b} \text { for } \lambda_{\text {eff }} \text { according to new } \\
\text { method, } \mathrm{m} \cdot \mathrm{K} \cdot \mathrm{W}^{-1}\end{array}$ & 0.1290 & 0.1290 & 0.1270 & 0.1320 & 0.1310 & 0.1270 & 0.1300 & 0.1290 \\
\hline $\begin{array}{c}\text { Relative change of } R_{b} \text { with } \\
\text { respect to full } \\
\text { measurement range, } \%\end{array}$ & 0.00 & 0.00 & 1.55 & $\underline{-2.33}$ & -1.55 & 1.55 & -0.78 & 0.00 \\
\hline $\begin{array}{l}\text { Effective thermal } \\
\text { conductivity } \lambda_{\text {eff }} \text { in } \mathrm{BHE} \text { for } \\
\text { mean temperature of heat } \\
\text { carrier according to new } \\
\text { method, } \mathrm{W} \cdot \mathrm{m}^{-1} \cdot \mathrm{K}^{-1}\end{array}$ & 2.7666 & 2.7620 & 2.6970 & 2.9745 & 2.8337 & 2.7173 & 2.8262 & 2.7598 \\
\hline $\begin{array}{c}\text { Relative change of } \lambda_{\text {eff }} \text { with } \\
\text { respect to full } \\
\text { measurement range, } \%\end{array}$ & 0.00 & 0.17 & 2.52 & $\underline{-7.51}$ & -2.43 & 1.78 & -2.15 & 0.25 \\
\hline
\end{tabular}


Table 7. BHE thermal resistivity $R_{b}$ and effective thermal conductivity $\lambda_{\text {eff, }}$, determined using the new method for various data intervals (for TRT at Laboratory of Geoenergetics).

\begin{tabular}{|c|c|c|c|c|c|c|c|c|}
\hline Data & $\begin{array}{l}\text { Full Range } \\
\text { of Data }\end{array}$ & $\begin{array}{l}\text { From Slope to } \\
\text { End of TRT }\end{array}$ & $\begin{array}{l}\text { From } t=5 r_{o}^{2} \alpha^{-1} \\
\text { to End of TRT }\end{array}$ & $\begin{array}{l}\text { From Beginning } \\
\text { to } t=5 r_{o}^{2} \alpha^{-1}\end{array}$ & $\begin{array}{l}\text { From Beginning } \\
\text { to } t=20 r_{o}^{2} \alpha^{-1}\end{array}$ & $\begin{array}{l}\text { From } t=5 r_{o}^{2} \alpha^{-1} \\
\text { to } t=20 r_{o}^{2} \alpha^{-1}\end{array}$ & $\begin{array}{l}\text { From Slope to } \\
\text { Half Time of Full } \\
\text { Range of Data }\end{array}$ & $\begin{array}{l}\text { From } t=20 r_{o}^{2} \alpha^{-1} \\
\text { to End of TRT }\end{array}$ \\
\hline & $t_{0}$ to $t_{5}$ & $t_{1}$ to $t_{5}$ & $t_{2}$ to $t_{5}$ & $t_{0}$ to $t_{2}$ & $t_{0}$ to $t_{3}$ & $t_{2}$ to $t_{3}$ & $t_{1}$ to $t_{4}$ & $t_{3}$ to $t_{5}$ \\
\hline $\begin{array}{c}R_{b} \text { for } \lambda_{\text {eff }} \text { according to new } \\
\text { method, } \mathrm{m} \cdot \mathrm{K} \cdot \mathrm{W}^{-1}\end{array}$ & 0.1340 & 0.1340 & 0.1380 & 0.1310 & 0.1300 & 0.1290 & 0.1300 & 0.1470 \\
\hline $\begin{array}{l}\text { Relative change of } R_{b} \text { with } \\
\text { respect to full } \\
\text { measurement range, \% }\end{array}$ & 0.00 & 0.00 & -2.99 & 2.24 & 2.99 & 3.73 & 2.99 & -9.70 \\
\hline $\begin{array}{c}\text { Effective thermal } \\
\text { conductivity } \lambda_{\text {eff }} \text { in BHE for } \\
\text { mean temperature of heat } \\
\text { carrier according to new } \\
\text { method, } \mathrm{W} \cdot \mathrm{m}^{-1} \cdot \mathrm{K}^{-1}\end{array}$ & 1.9829 & 1.9738 & 2.0397 & 1.9872 & 1.8714 & 1.8588 & 1.8968 & 2.1751 \\
\hline $\begin{array}{l}\text { Relative change of } \lambda_{\text {eff }} \text { with } \\
\text { respect to full } \\
\text { measurement range, } \%\end{array}$ & 0.00 & 0.46 & -2.86 & -0.22 & 5.62 & 6.26 & 4.34 & -9.69 \\
\hline
\end{tabular}




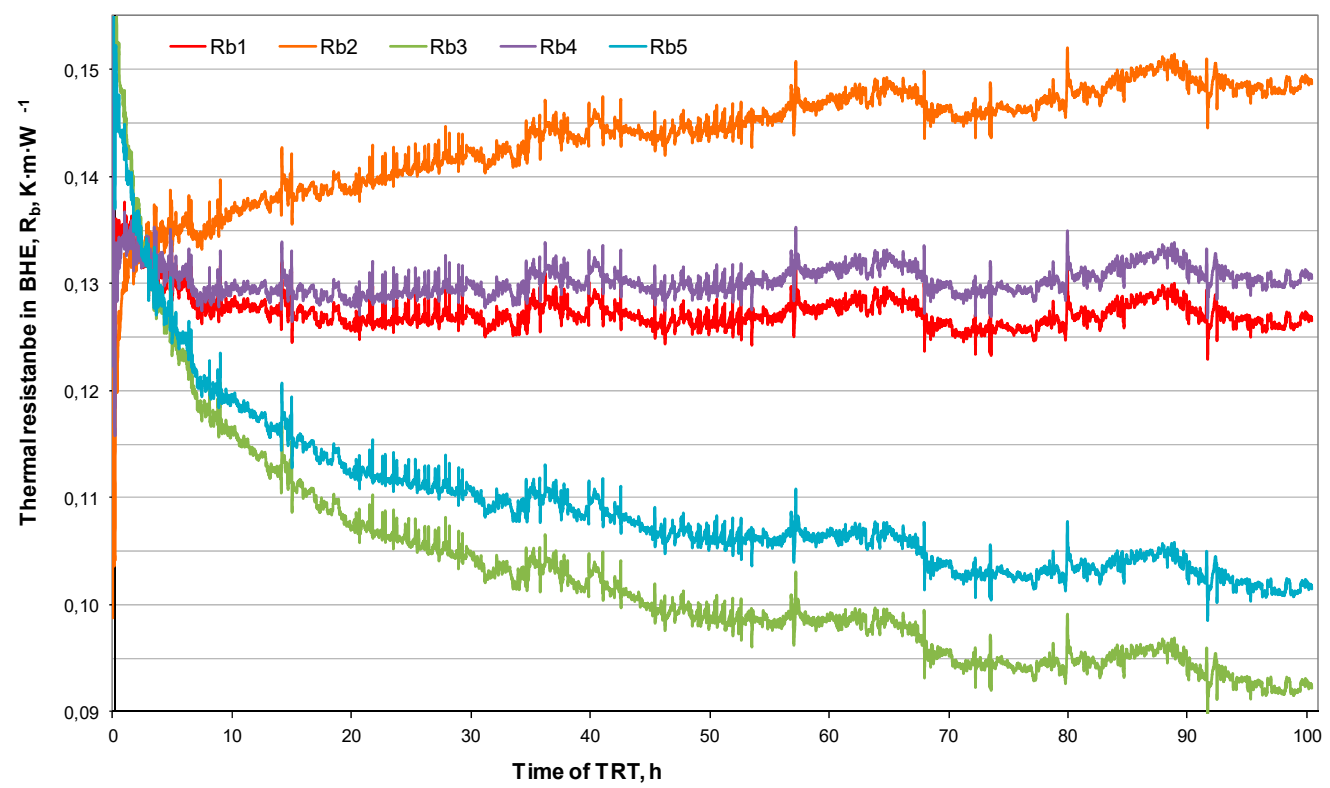

Figure 5. Thermal resistivity of BHE vs. TRT time, where $R_{b 1}, R_{b 2}, R_{b 3}, R_{b 4}$, and $R_{b 5}$ are described in the text.

\section{Results and Discussion}

The thermal response test is the most favored way of determining the basic BHE parameters. The effective thermal conductivity $\lambda_{\text {eff }}$ is the most important value for characterizing a BHE, and it is used for determining its energy efficiency. The effective thermal conductivity is mainly dependent on the thermal conductivity of rocks $\lambda$, especially when the BHE has been correctly performed. In reality, $\lambda_{\text {eff }}$ is also dependent on the heat transfer resistivity between the heating agent circulating in the BHE and the rock mass. This heat transfer resistivity accounts for:

- transfer of heat from the heating agent to the material (most frequently U-tubes), which depends on, among other factors, its viscosity;

- heat conduction through the material (U-tube), which is affected by its thermal conductivity, e.g., for the case of a polyethylene tube $\lambda=0.42 \mathrm{~W} \cdot \mathrm{m}^{-1} \cdot \mathrm{K}^{-1}$;

- heat flow between the material of U-tube and the BHE filling/sealing material, where discontinuities may occur; and,

- Heat flow between the BHE filling/sealing material and rock mass, where some discontinuities may be encountered.

An analysis of the experimental and analytical results reveals that, despite a correctly performed TRT, the values of $\lambda_{\text {eff }}$ are not constant with the time of test. This is caused by the assumed duration of the test. Such differences with respect to the value that was obtained for the full time of the test $(100 \mathrm{~h})$ may as great as $16.50 \%$, relative to the traditional method (Table 5), and $9.69 \%$ for the new method (Table 7). The greatest percentage difference between the values of $\lambda_{\text {eff }}$ and $R_{b}$ are underlined in bold in Tables 4-7. The relative change of $R_{b}$ or $\lambda_{\text {eff }}$ with respect to the full measurement range is calculated in $\%$, relative to the values in the first time interval $\left(t_{0}\right.$ to $\left.t_{5}\right)$. Accordingly, the percentage difference for this interval (i.e., the full range of data, $t_{0}$ to $t_{5}$ ) is always zero.

The new method is observed to be more accurate and stable in time for calculating the effective thermal conductivity $\lambda_{\text {eff }}$ in BHEs. However, when analyzing the BHE thermal resistivity $R_{b}$, larger discrepancies can be observed for relative deviations from the basic value (for the full test duration). A maximum deviation of $1.80 \%$ for the traditional method (Table 5) and $9.70 \%$ for the new method is observed (Table 7). The greatest differences are observed for the TRT performed at the Laboratory of Geoenergetics, Faculty of Drilling, Oil, and Gas, AGH University of Science and Technology. For TRTs 
performed in Żarów, the corresponding deviations are much smaller. Therefore, more analyses of TRT data are needed while using the new methodology to assess these discrepancies, and that is the topic of ongoing research by the authors.

Many more analyses of TRT results are needed, along with the corresponding statistical analyses, to choose a better method for the interpretation of TRT results. In practice, there is no ideal TRT. The functional variation of temperature with time has many distortions. Simultaneously with improving TRT interpretations, the TRT measuring procedure also needs improvement. The inflow of material at the outside temperature should be reduced/eliminated, and a reliable automatic system is needed for maintaining a constant heating power when the variable voltages are present in the electrical network. Both of these requirements are being addressed at the Laboratory of Geoenergetics.

The accuracy of the calculation of the effective thermal conductivity coefficient and the thermal resistance has not been extensively examined in this article. That is because the target of this article is to describe the new methodology. Research by the present authors is ongoing to assess the precision of the results that were obtained with the new method, and it is expected to be reported soon.

\section{Conclusions}

The thermal response test is the most accurate way of determining parameter values of borehole heat exchangers. The effective thermal conductivity $\lambda_{\text {eff }}$ and thermal resistivity of borehole $R_{b}$ can be used in the design of an appropriate number of borehole exchangers for a given heating power demand and for a given time duration.

However, when interpreting the thermal response test, there are sometimes problems with the resulting values. That is, the values of thermal conductivity $\lambda_{\text {eff }}$ and thermal resistivity $R_{b}$ can differ depending on the assumed range of data, especially the time data. Various values of basic parameters are seen to be obtained, even for correctly performed tests, when analyzing various TRT time intervals.

The proposed method of determining basic TRT parameters is based on the BHE thermal resistivity $R_{b}$ equation. This dependence (Equation (9)) is also observed to be a function of effective thermal conductivity $\lambda_{\text {eff }}$ of the borehole heat exchanger. It is suggested that, a pair of the test results, i.e., effective thermal conductivity $\lambda_{e f f}$ and BHE thermal resistivity $R_{b}$, can predict the dependence of resistivity as a function of time, such that the slope coefficient of the regression line that is based on this approach is zero.

It is concluded from the analyses that the proposed new method of determining the values of the basic parameters of a BHE is more accurate and independent of thermal response test duration. The differences that were obtained for various TRT times with the proposed method for $\lambda_{\text {eff }}$ are lower than with the traditional method. However, larger differences are obtained for $R_{b}$. Further work to assess the usefulness of this method in the interpretation of TRT data appears to be merited.

Author Contributions: Conceptualization, A.S.-S., A.G. and M.A.R.; methodology, A.S.-S.; software, T.S.; validation, A.S.-S. and T.S.; formal analysis, J.K.; investigation, T.S.; resources, A.S.-S. and A.G.; data curation, T.S.; writing, reviewing and editing of manuscript, A.S.-S., T.S. and M.A.R.; visualization, T.S.; supervision, A.S.-S.; project administration, A.S.-S.; funding acquisition, A.S.-S. and T.S.

Funding: This research was funded by statutory research programme at the Faculty of Drilling, Oil and Gas, AGH University of Science and Technology in Krakow, Poland, grant number 11.11.190.555.

Conflicts of Interest: The authors declare no conflict of interest.

\section{Nomenclature/Glossary}

$b \quad$ thickness of pipe of U-tube (mm)

$c_{p} \quad$ specific heat at constant pressure of ground $\left(\mathrm{J} \mathrm{kg}^{-1} \mathrm{~K}^{-1}\right)$

$c_{f} \quad$ specific heat of heat carrier $\left(\mathrm{J} \mathrm{kg}^{-1} \mathrm{~K}^{-1}\right)$

$D_{0} \quad$ borehole diameter $(\mathrm{m})$

$d_{z} \quad$ outer diameter of pipe of U-tube $(\mathrm{m})$

$H$ depth of BHE (m) 


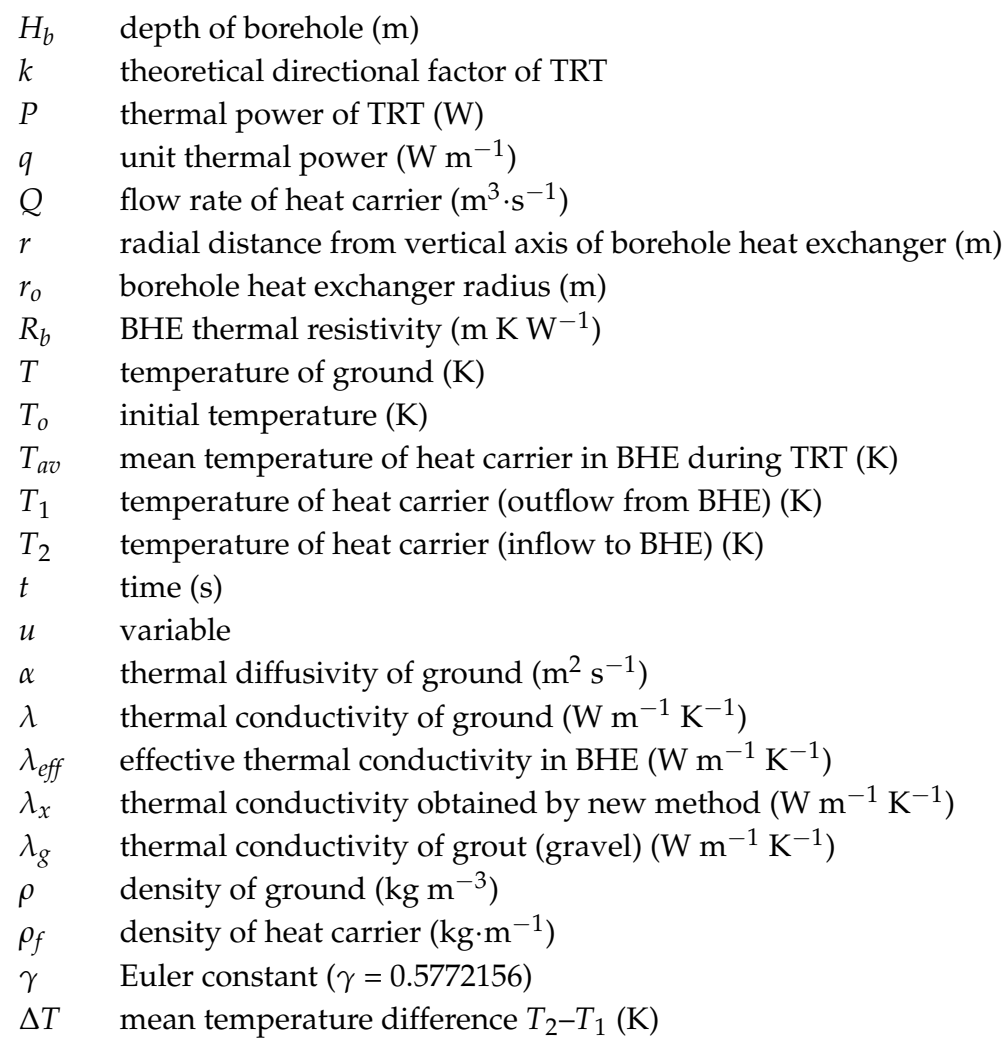

\section{References}

1. Rybach, L.; Eugster, W.J. Sustainability aspects of geothermal heat pump operation, with experience from Switzerland. Geothermics 2010, 39, 365-369. [CrossRef]

2. Weber, J.; Ganz, B.; Schellschmidt, R.; Sanner, B.; Schulz, R. Geothermal energy use in Germany. In Proceedings of the World Geothermal Congress, Melbourne, Australia, 19-25 April 2015.

3. Gehlin, S.; Andersson, O.; Bjelm, L.; Alm, P.G.; Rosberg, J.E. Country update for Sweden. In Proceedings of the World Geothermal Congress, Melbourne, Australia, 19-25 April 2015.

4. Raymond, J.; Malo, M.; Tanguay, D.; Grasby, S.; Bakhteyar, F. Direct utilization of geothermal energy from coast to coast: A review of current applications and research in Canada. In Proceedings of the World Geothermal Congress, Melbourne, Australia, 19-25 April 2015.

5. Boyd, T.L.; Sifford, A.; Lund, J.W. The United States of America country update 2015. In Proceedings of the World Geothermal Congress, Melbourne, Australia, 19-25 April 2015.

6. Dincer, I.; Rosen, M.A. Thermal Energy Storage: Systems and Applications, 2nd ed.; Wiley: London, UK, 2011.

7. Kizilkan, O.; Dincer, I. Borehole thermal energy storage system for heating applications: Thermodynamic performance assessment. Energy Convers. Manag. 2015, 90, 53-61. [CrossRef]

8. Sliwa, T.; Rosen, M.A. Natural and artificial methods for regeneration of heat resources for borehole heat exchangers to enhance the sustainability of underground thermal storages: A review. Sustainability 2015, 7, 13104-13125. [CrossRef]

9. Beier, R.A.; Acuña, J.; Mogensen, P.; Palm, B. Borehole resistance and vertical temperature profiles in coaxial borehole heat exchangers. Appl. Energy 2013, 102, 665-675. [CrossRef]

10. Zarrella, A.; De Carli, M. Heat transfer analysis of short helical borehole heat exchangers. Appl. Energy 2013, 102, 1477-1491. [CrossRef]

11. Zarrella, A.; Capozza, A.; De Carli, M. Analysis of short helical and double U-tube borehole heat exchangers: A simulation-based comparison. Appl. Energy 2013, 112, 358-370. [CrossRef]

12. Li, M.; Lai, A.C.K. Heat-source solutions to heat conduction in anisotropic media with application to pile and borehole ground heat exchangers. Appl. Energy 2012, 96, 451-458. [CrossRef]

13. Knez, D. Stress State Analysis in Aspect of Wellbore Drilling Direction. Arch. Min. Sci. 2014, 59, 69-74. [CrossRef] 
14. Lee, C.; Moonseo, P.; Sunhong, M.; Shin-Hyung, K.; Byonghu, S.; Hangseok, C. Comparison of effective thermal conductivity in closed-loop vertical ground heat exchangers. Appl. Therm. Eng. 2011, 31, 3669-3676. [CrossRef]

15. Lee, C.; Moonseo, P.; The-Bao, N.; Byonghu, S.; Jong, M.C.; Hangseok, C. Performance evaluation of closed-loop vertical ground heat exchangers by conducting in-situ thermal response tests. Renew. Energy 2012, 42, 77-83. [CrossRef]

16. Yavuzturk, C.; Chiasson, A.D. Performance analysis of U-tube, concentric tube, and standing column well ground heat exchangers using a system simulation approach. ASHRAE Trans. 2002, 108, 925.

17. Li, X.; Yan, C.; Zhihao, C.; Jun, Z. Thermal performances of different types of underground heat exchangers. Energy Build. 2006, 38, 543-547. [CrossRef]

18. Zarrella, A.; Emmi, G.; Graci, S.; De Carli, M.; Cultrera, M.; Santa, G.D.; Galgaro, A.; Bertermann, D.; Müller, J.; Pockelé, L.; et al. Thermal Response Testing Results of Different Types of Borehole Heat Exchangers: An Analysis and Comparison of Interpretation Methods. Energies 2017, 10, 801. [CrossRef]

19. Kurevija, T.; Vulin, D.; Krapec, V. Effect of borehole array geometry and thermal interferences on geothermal heat pump system. Energy Convers. Manag. 2012, 60, 134-142. [CrossRef]

20. Jaszczur, M.; Polepszyc, I.; Sapinska-Sliwa, A. Numerical analysis of the boundary conditions model impact on the estimation of heat resources in the ground. Pol. J. Environ. Stud. 2015, 24, 60-66.

21. Jaszczur, M.; Polepszyc, I.; Sapińska-Śliwa, A.; Gonet, A. An analysis of the numerical model influence on the ground temperature profile determination. J. Therm. Sci. 2017, 26, 82-88. [CrossRef]

22. Sliwa, T.; Rosen, M.A. Efficiensy analysis of borehole heat exchangers as grout varies via thermal response test simulation. Geothermics 2017, 69, 132-138. [CrossRef]

23. Eslami-nejad, P.; Bernier, M. Freezing of geothermal borehole surroundings: A numerical and experimental assessment with applications. Appl. Energy 2012, 98, 333-345. [CrossRef]

24. Deqi Wang, D.; Lu, L.; Zhang, W.; Cui, P. Numerical and analytical analysis of groundwater influence on the pile geothermal heat exchanger with cast-in spiral coils. Appl. Energy 2015, 160, 705-714. [CrossRef]

25. Chiasson, A.C.; Rees, S.J.; Spitler, J.D. A preliminary assessment of the effects of ground-water flow on closed-loop ground-source heat pump systems. ASHRAE Trans. 2000, 106, 380-393.

26. Diao, N.; Li, Q.; Fang, Z. Heat transfer in ground heat exchangers with groundwater advection. Int. J. Therm. Sci. 2004, 43, 1203-1211. [CrossRef]

27. Fujii, H.; Itoi, R.; Fujii, J.; Uchida, Y. Optimizing the design of large-scale ground-coupled heat pump systems using groundwater and heat transport modelling. Geothermics 2005, 34, 347-364. [CrossRef]

28. Hecht-Méndez, J.; de Paly, M.; Beck, M.; Bayer, P. Optimization of energy extraction for vertical closed-loop geothermal systems considering groundwater flow. Energy Convers. Manag. 2013, 66, 1-10. [CrossRef]

29. Molina-Giraldo, N.; Blum, P.; Zhu, K.; Bayer, P.; Fang, Z. A moving finite line source model to simulate borehole heat exchangers with groundwater advection. Int. J. Therm. Sci. 2011, 50, 2506-2513. [CrossRef]

30. Fan, R.; Jiang, Y.Q.; Yao, Y.; Shiming, D.; Ma, Z.L. A study on the performance of a geothermal heat exchanger under coupled heat conduction and groundwater advection. Energy 2007, 32, 2199-2209. [CrossRef]

31. Sliwa, T.; Nowosiad, T.; Vytyaz, O.; Sapinska-Sliwa, A. Study on efficiency of deep borehole heat exchangers. SOCAR Proc. 2016, 2, 29-42. [CrossRef]

32. Luo, J.; Rohn, J.; Bayer, M.; Priess, A. Thermal Efficiency Comparison of Borehole Heat Exchangers with Different Drillhole Diameters. Energies 2013, 6, 4187-4206. [CrossRef]

33. Sanner, B.; Mands, E.; Sauer, M.; Grundmann, E. Economic aspects of thermal response test-advantages, technical improvements, commercial application. In Proceedings of the Effstock 2009: International Conference on Thermal Energy Storage, Stockholm, Sweden, 14-17 June 2009; pp. 1-9.

34. Acuña, J.; Palm, B. Distributed thermal response tests on pipe-in-pipe borehole heat exchangers. Appl. Energy 2013, 109, 312-320. [CrossRef]

35. Zhang, L.; Zhang, Q.; Huang, G.; Du, Y. A p(t)-linear average method to estimate the thermal parameters of the borehole heat exchangers for in situ thermal response test. Appl. Energy 2014, 131, 211-221. [CrossRef]

36. Choi, W.; Ooka, R. Interpretation of disturbed data in thermal response tests using the infinite line source model and numerical parameter estimation method. Appl. Energy 2015, 148, 476-488. [CrossRef]

37. Li, Y.; Mao, J.; Geng, S.; Han, X.; Zhang, H. Evaluation of thermal short-circuiting and influence on thermal response test for borehole heat exchanger. Geothermics 2014, 50, 136-147. [CrossRef]

38. Witte, H.L.J. Error analysis of thermal response tests. Appl. Energy 2013, 109, 302-311. [CrossRef] 
39. Eskilson, P. Thermal Analyses of Heat Extraction Boreholes. Ph.D. Thesis, Department of Mathematical Physics, Lund Institute of Technology, Lund, Sweden, 1987.

40. Sliwa, T.; Gonet, A. Theoretical model of borehole heat exchanger. J. Energy Resour. Technol. 2005, 127, 142-148. [CrossRef]

41. Sliwa, T.; Gołaś, A.; Wołoszyn, J.; Gonet, A. Numerical model of borehole heat exchanger in ANSYS CFX software. Arch. Min. Sci. 2012, 57, 375-390.

42. Sliwa, T.; Kotyza, J. Application of existing wells as ground heat source for heat pumps in Poland. Appl. Energy 2003, 74, 3-8. [CrossRef]

43. Baria, R.; Michelet, S.; Baumgaertner, J.; Dyer, B.; Gerard, A.; Nicholls, J.; Hettkamp, T.; Teza, D.; Soma, N.; Asanuma, H.; et al. Microseismic monitoring of the world's largest potential HDR reservoir. In Proceedings of the 29th Workshop on Geothermal Reservoir Engineering, Stanford University, Stanford, CA, USA, 26-28 January 2004.

44. Valley, B.; Evans, K.F. Stress Orientation at the Basel Geothermal Site from Wellbore Failure Analysis in BS1, Report to Geopower Basel AG for Swiss Deep Heat Mining Project Basel. ETH Report Nr.: ETH 3465/56; Ingenieurgeologie ETH: Zürich, Switzerland, 2006.

45. Lamarche, L.; Raymond, J.; Koubikana Pambou, C.H. Evaluation of the Internal and Borehole Resistances during Thermal Response Tests and Impact on Ground Heat Exchanger Design. Energies 2018, 11, 38. [CrossRef]

46. Badenes, B.; Mateo Pla, M.Á.; Lemus-Zúñiga, L.G.; Sáiz Mauleón, B.; Urchueguía, J.F. On the Influence of Operational and Control Parameters in Thermal Response Testing of Borehole Heat Exchangers. Energies 2017, 10, 1328. [CrossRef]

47. Perina, T. Derivation of the Theis (1935) Equation by Substitution. Ground Water 2010, 48, 6-7. [CrossRef]

48. Sanner, B.; Hellström, G.; Spitler, J.; Gehlin, S. Thermal Response Test-Current Status and World-Wide Application. In Proceedings of the World Geothermal Congress 2005, Antalya, Turkey, 24-29 April 2005.

49. Sliwa, T.; Gonet, A. Otworowe wymienniki ciepła jako źródło ciepła lub chłodu na przykładzie Laboratorium Geoenergetyki WWNiG AGH. Wiertnictwo Nafta Gaz 2011, 28, 419-430. (In Polish)

50. Sliwa, T.; Rosen, M.A.; Jezuit, Z. Use of oil boreholes in the Carpathians in geoenergetics systems historical and conceptual review. Res. J. Environ. Sci. 2014, 8, 231-242. [CrossRef]

51. Gonet, A.; Sliwa, T.; Stryczek, S.; Sapinska-Sliwa, A.; Pająk, L.; Jaszczur, M.; Złotkowski, A. Metodyka Identyfikacji Potencjału Cieplnego Górotworu wraz z Technologia Wykonywania i Eksploatacji Otworowych Wymienników Ciepła; Gonet, A., Ed.; Wydawnictwa Uczelniane AGH: Krakow, Poland, 2011. (In Polish)

52. Plewa, S. Rozkład Parametrów Geotermalnych na Obszarze Polski; Wydawnictwo CPPGSMiE PAN: Krakow, Poland, 1994. (In Polish)

53. Somerton, W.H. Thermal Properties and Temperature-Related Behavior of Rock/Fluid Systems; Elsevier: Amsterdam, The Netherlands, 1992.

54. Rohner, E.; Rybach, L.; Schärli, U. A New, Small, Wireless Instrument to Determine Ground Thermal Conductivity In-Situ for Borehole Heat Exchanger Design. In Proceedings of the World Geothermal Congress, Antalya, Turkey, 24-29 April 2005; pp. 1-4.

(C) 2019 by the authors. Licensee MDPI, Basel, Switzerland. This article is an open access article distributed under the terms and conditions of the Creative Commons Attribution (CC BY) license (http:// creativecommons.org/licenses/by/4.0/). 